\title{
The Agenda Setting Policy for Hajj and Umrah in Post Pandemic
}

\author{
Intan Fitri Meutia ${ }^{1, *}$ Bayu Sujadmiko ${ }^{2,}$ Devi Yulianti ${ }^{1,}$ Kristian Adi Putra $^{3,}$ Savira Nur \\ Aini $^{1}$ \\ ${ }^{1}$ Public Administration Department, Social and Political Sciences Faculty, Universitas Lampung \\ 2 International Law Department, Law Faculty, Universitas Lampung \\ ${ }^{3}$ Prince Sattam Bin Abdul Aziz University \\ *Corresponding author. Email: intan.fitri@fisip.unila.ac.id
}

\begin{abstract}
The total number of Muslims in Indonesia is estimated at $13 \%$ of the total number of Muslims in Indonesia world. Indonesia is the second-largest country that sends pilgrims for Hajj and Umrah every year after Pakistan. Due to the global COVID-19 Pandemic, the Kingdom government of Saudi Arabia has decided to temporarily suspend the Umrah and Hajj pilgrimages only for residents with a minimal number and very strict. Therefore, it is necessary to formulate a policy model to implement Hajj and Umrah during the COVID-19 Pandemic. This research is qualitative descriptive research, wherein this research will be described and analyze the schedule of setting policies for Hajj and Umrah during the COVID-19 Pandemic in Indonesia. The stages of agenda-setting and policy formulation to formulate the model will be prioritized by mapping the 4Ps, namely: Power (strength/power), Perception (Perception); potency (Potency); Proximity (closeness). The mapping procedure of the agenda-setting hoped that a government policy model emerged through the Ministry of Religion as the party responsible for organizing the Hajj and Umrah pilgrimages who are always obliged to strive to provide the best service to the community.
\end{abstract}

Keywords: Agenda setting, Covid-19, Hajj Umrah, and Policy

\section{INTRODUCTION}

As a country with the largest Muslim population globally, Indonesia sends many pilgrims for Hajj and Umrah every year. From 2016 to 2019 , the number of enthusiasts or registrants for Hajj pilgrims nationally increased every year. At the beginning of 2020, on January 30, the World Health Organization (WHO) officially declared the novel coronavirus disease 2019 (COVID-19) as an international public health emergency of concern. It causes the queue/waiting list for the pilgrimage in Indonesia to be estimated at 20 years. These problems significantly impact the social, economic, political, and religious fields worldwide [1].

There are some problems related to the implementation of the Hajj during the post-pandemic until now. There has been no other policy that regulates in detail the Hajj implementation following the pandemic context. There are two kinds of policies in Hajj in Indonesia, namely policies from the Central Ministry of Religion and policies from the Government of Saudi Arabia. Usually, the Government of Saudi Arabia issues a policy when approaching the implementation of the Hajj departure, which is a consideration for the Ministry of Religion whether it is ready to send pilgrims or vice versa. For the discourse on the departure of Hajj and Umrah pilgrims during the Pandemic, there are 3 (three) scenarios including (1) Organizing Hajj with pilgrims departing with a full quota; (2) Pilgrims are dispatched with a limited quota; (3) Pilgrims for Hajj 2021 will not depart as in 2020.

In a public policy, the stages of making an excellent public policy, according to AG Subarsono, consist of agenda-setting, policy formulation, policy adoption, policy implementation, and policy evaluation [2]. The agenda-setting stage is an essential part of the policymaking stage to raise the Government's plan to be further resolved through policy actions. The Ministry of Religion responsible for organizing the Hajj and Umrah pilgrimages is obliged to give special attention in the form of appropriate policies related to the implementation of Hajj and Umrah following the 
context of the COVID-19 Pandemic. Through research entitled "The Agenda-Setting Policy for Hajj and Umrah Post Pandemic."

\section{LITERATURE REVIEW}

\subsection{The Concept of Public Policy}

Andriansyah states that public policy or public policy is a set rule and must be obeyed. Anyone who violates it will be subject to sanctions according to the weight of the violation committed [3]. According to Charles O. Jones, a policy has components, including Goal, which is the goal to be achieved; Plans or proposals, namely a more specific understanding to achieve goals; Program, namely the efforts made by the authorities in achieving the objectives; Decision or decisions, namely actions in determining goals, making plans, implementing and evaluating programs; Effects, namely the consequences resulting from the existence of the program, whether intentional or unintentional, primary or secondary [4].

Normative context of organizing the pilgrimage according to Article 21 of Law no. 8 of 2019, the Government is responsible for implementing Hajj, which the Minister carries out through the Ministry of Religion as the person in charge of carrying out Hajj and Umrah. Normatively, policymaking actors consist of the legislature, executive, administrative, and judges. Stakeholders are directly or indirectly influenced by something and are interested in a project [5]. They can be individuals, groups, or people, both men and women involved, have an interest, or are influenced (positively or negatively) by an activity in a development program. In this study, stakeholders in implementing the Hajj and Umrah pilgrimages can be seen in Table 1 .

Table 1. Stakeholders in Hajj and Umrah Pilgrimage

\begin{tabular}{ll}
\hline No. & \multicolumn{1}{c}{$\begin{array}{c}\text { Hajaj and Umrah } \\
\text { anelders in the Implementation of }\end{array}$} \\
\hline 1. Ministry of Hajj and Umrah Saudi Arabia \\
2. Department of Transportation \\
3. Immigration \\
4. Hajj Deposit Receiving Bank \\
5. Hajj Guidance Group \\
6. Office of Religious Affairs \\
7. Hajj Supervisory Commission consists of \\
the Indonesian Muslim Council, Islamic \\
community organizations, and Islamic \\
community leaders.
\end{tabular}

Source: Research Observation, 2021

According to William N. Dunn, the stages in public policy begin with preparing the policy agenda, policy formulation, policy adoption, policy implementation, and policy evaluation [6]. Based on the stages in making public policy above, this research focuses on the agenda-setting stage.

\subsection{Public Issues}

Policy issues are often referred to as policy problems. Issues are not only understood as public problems that conflict or contradict each other (controversial public problems) but can also be interpreted as differences of opinion in the community both regarding perceptions and solutions to a public problem. There are four main characteristics of policy problems: Interdependence; Subjectivity; Artificial properties; The dynamics of policy issues [7]. In terms of hajj and Umrah during the COVID-19 Pandemic, problems occur not only in one religious aspect but also in political, social, and health aspects. In organizing Hajj and Umrah during the COVID-19 Pandemic, a policy is needed that will be able to overcome the problems of Hajj and Umrah during the COVID-19 Pandemic.

\subsection{The Concept of Hajj and Umrah}

Linguistically, Hajj is defined as deliberately heading to a place that is glorified. Worship performed by Muslims to the Baitullah in Mecca because it is a place that is glorified and sanctified by Muslims. In the sense of the term syari', Hajj is understood as intentionally visiting the $K a^{\prime} b a h$ to perform certain practices at a particular time with certain conditions and procedures. While Umrah, according to the language, can be interpreted as a pilgrimage. According to the term syari', Umrah has the means of visiting the Ka'bah to perform certain practices. The term used for Hajj and Umrah at the same time is Nusuk. Nusuk is 'obedience' to get closer to Allah, the most important [8].

\section{FINDINGS}

\subsection{Strategic Plan of the Regional Office of the Ministry of Religion of Lampung Province for 2020-2024}

Hajj is the fifth pillar of Islam, an obligation at least once in a lifetime for every Muslim who can perform it. According to Article 9 of Law Number 6 of 2019 concerning the Implementation of Hajj and Umrah, it is stated that the Government is responsible for the Organizing of Regular Hajj and Umrah, which are carried out by the Directorate General of Hajj and Umrah. To improve the quality of services, in 2019, 10 innovations were made in the Organization of the Hajj, namely: (1) One use of the integrated Hajj report system (Smart Hajj) in the Group Officer Report; (2) Moderation of the pilgrimage through strengthening the rituals, with the addition of material on the history of the pilgrimage. 
The high level of Hajj satisfaction was obtained as a result of the revitalization of the hajj dormitories, the construction in the region, the development of the hajj registration system, the development of hajj services in the implementation of the zoning system for accommodation placement, the development of an online licensing system for Hajj and Umrah, and optimization of hajj funds. When broken down by type of service, the highest satisfaction value is found in the regular Hajj registration service at the Regency or City Ministry of Religion office. Meanwhile, the Embarkation Hajj Organizing Committee service at the Hajj Dormitory is at the lowest value.

In the field of Umrah, the Regional Office of the Ministry of Religion of Lampung Province has carried out guidance on the implementation of Umrah worship through institutional strengthening, online Umrah licensing, and accreditation. Institutional strengthening by increasing coordination between institutions and regional work units, namely: empowering Islamic Religion Affairs extension workers. Electronic Umrah licensing service activities consist of; (1) application for an operational permit as Umrah agent; (2) changes to data; and (3) submission of application for accreditation.

Since 2016-2019, the Ministry of Religion has established 24 Umrah agents' operational permits. In addition, the Regional Office of the Ministry of Religion of Lampung Province also continues to make improvements in the supervision and handling of Umrah cases. The evidence is resolving domestic problems, enforcing discipline/law, airport supervision/integrated airport surveillance teams, and strengthening the Regency/City Ministry of Religious Affairs role.

Moreover, below is the result from interviews done to six persons (2 from the Ministry of Religious, two from the Ministry of Health, one from the private sector as tour and travel representative who held Hajj and Umrah, one from the candidate of Hajj)

\subsection{The Agenda Setting Policies for the Implementation of Hajj and Umrah during Post Pandemic}

Activities to make public problems (public problems) into policy problems (policy problems) are often referred to as agenda-setting (Agenda setting) [10]. The agenda is a specific pattern of government action, which analyzes how a problem is defined, developed, formulated and the solution made. In public policy, Agenda Setting (problem formulation) is a critical step that must be passed when an issue enters and can be raised on the Government's plan. At the problem formulation stage, not all problems can be categorized as a policy agenda. Then the issue is not discussed, some are designated as the focus of policy, and some are postponed for specific reasons for an undetermined time.

According to Puspita, activities to make public problems into policy problems are often referred to as agenda-setting. Agenda setting is also the first step of a public policy process in responding to an issue in society and requires a solution to solve the problem [9]. In this case, the researcher tries to describe and analyze how the issues are the subject of problem formulation in organizing Hajj and Umrah during the COVID-19 Pandemic in Lampung Province.

Hajj and Umrah are worship that every Muslim in the world wants. The fifth pillar of Islam, the Hajj, can only be performed once a year at a particular time between the 8th and 13th of Dhulhijjah. Terminologically, Hajj can be interpreted as visiting the Baitullah to perform several practices, including wukuf, tawaf, $s a^{\prime} i$, and other practices at certain times, to fulfill Allah's call and expect His pleasure. Hajj can be performed once a year, while the implementation of Umrah can be done throughout the year and is considered a shorter pilgrimage. Hajj and Umrah, according to Jokhdar, is one of the series of worship that involves the most significant number of masses in the world because it involves millions of Muslims from 180 countries every year. In principle, the State is fully responsible for implementing the pilgrimage as stated in Article 29 Paragraph 2 of the 1945 Constitution, which the Minister carries out through the Ministry of Religion of the Republic of Indonesia.

Entering the beginning of 2020, the World Health Organization (WHO) officially declared Novel Coronavirus Disease 2019 (COVID-19) as an international public health emergency of concern. After that, WHO classified the presence of COVID-19 as a global pandemic since March 11, 2020. This Pandemic has had an impact on the implementation of Hajj and Umrah. The existence of the COVID-19 Pandemic that has attacked almost the entire world since the end of 2019 has implemented the Hajj and Umrah pilgrimages in 2020 undergo many changes. Previously, the world had experienced pandemic crises several times, but in this case, COVID-19 has shown another unprecedented impact both at the national and international levels. This has an impact on every country, including Indonesia, which will later organize hajj and Umrah. As the party responsible for organizing $\mathrm{Hajj}$ in Indonesia, the Government should make an adjustment policy, including the Government of Saudi Arabia as the host of the Hajj and Umrah. As an initial stage in policymaking, setting policies for Hajj and Umrah during the COVID19 Pandemic is the primary step from which an issue or 
problem that occurs can be raised on the Government's plan to be resolved through policy actions.

In this study, the researcher describes the results relating to what issues are the main problems in the Policy Setting Agenda for Hajj and Umrah during the COVID-19 Pandemic, which can be seen by using the theoretical model of The 4P's of Agenda Setting proposed by Zahariadis, including, by looking at the flow of Power, Potency, Perception, and Proximity (closeness) [10].

\subsubsection{Power}

According to the international media.kontan.co.id (accessed December 22, 2020), the 2020 Hajj and Umrah implementation during the COVID-19 Pandemic was limited and rigorous. The host of the Hajj, the Government of the Kingdom of Saudi Arabia, has decided that the Hajj is only held for a certain number of residents. Meanwhile, international pilgrims are prohibited from traveling to Mecca and Medina to perform Hajj and Umrah.

Power is the main factor that forms the basis for making government agendas, where a person or group of people can influence others to act or not act. In this flow of Power, parties who have Power have an essential role in problem formulation so that an issue can later be used as a government plan. The results of this research on the indicator of Power explain how the party has Powered in setting the policy plan for the implementation of Hajj and Umrah during the COVID19 Pandemic Lampung Province.

\subsubsection{Perception}

Based on interviews with six sources and documentation from the Ministry of Religion and Ministry of Health (vaccine book) that researchers have done. It can be concluded that in the Power stream, the owner of Power in the policy of organizing Hajj and Umrah during the COVID-19 Pandemic in Lampung Province is the Ministry of Religion of the Republic of Indonesia (central), taking into account the policies of the Ministry of Religion. Saudi Arabia is the host in organizing Hajj and Umrah. In deciding a policy in Hajj and Umrah, the Ministry of Religion involves related parties and is supervised by Commission VIII of the Indonesian House of Representatives. At the provincial or regional level, only technical implementers can still provide suggestions to the center through meetings held at the center.

Perception flow indicator or perception in question is an opinion that significantly influences what issues are considered essential and why the problem is essential. Results on the Perception stream, the researcher explained how the informants' opinions regarding the problems related to Hajj and Umrah were behind the formation of the policy-setting plan for the implementation of Hajj and Umrah during the COVID19 Pandemic in Lampung Province. The issues of Hajj and Umrah during the COVID-19 Pandemic are considered necessary, and why these problems are essential to be on the Government's plan. Measuring perceptions is needed to input the policy of adjusting the upcoming hajj and Umrah implementation through opinion mapping. In this case, the researcher will describe the results of research related to what and how the issues/problems that arise and develop on the broader community so that they are worthy of being used as a government plan regarding the implementation of Hajj and Umrah during the COVID-19 Pandemic in Lampung Province.

In addition, the Indonesian Government is also waiting for a decision from the Ministry of the Kingdom of Saudi Arabia whether they will accept pilgrims or not. With various health considerations and a minimum period to prepare for the implementation of the Hajj in the Holy Land, the Government then took the decision not to depart for the Hajj in advance. This is supported by various related parties and considers that the Government's decision is correct. In addition, the media is currently reporting a lot about the cancellation of the Indonesian Hajj, which can be a big question for pilgrims, such as the misuse of hajj funds.

\subsubsection{Potency}

The potency indicator refers to the intensity or severity of the consequences of a particular problem. In general, the greater the intensity or severity of the consequences of an issue, the more prominent it is on the Government's plan. The research results in the flow of the Potency indicator (potential or possibility) refers to the intensity of the severity of a problem related to the implementation of Hajj and Umrah during the COVID-19 Pandemic if the Government does not immediately anticipate the problem. The research results on this potential flow, researchers will describe the research results relating to the possibilities that will occur in formulating other problems/impacts if the problems are related to public policies that further regulate the implementation of the Hajj and Umrah during the COVID-19 Pandemic. 19 is not handled quickly and appropriately.

Based on interviews, it can be concluded that there will be many things that will happen to the organization of Hajj and Umrah during the upcoming COVID-19 Pandemic. Many possibilities will occur if the Government does not immediately handle the problems related to Hajj and Umrah. Among them are the possibility of additional costs, the quota for pilgrims 
departure will be reduced, the application of Health protocols, the age of the pilgrims is limited, mentally prepare prospective pilgrims with all the possibilities that will happen. Like it or not, the Government must immediately take action in the form of an adjustment policy (mitigation) and anticipate the possibilities that will occur. In addition, it is better if the manasik guidance is carried out by applying innovations and adapting to current conditions.

\subsubsection{Proximity}

The Proximity indicator in question is the Proximity of the problem that is felt directly to themselves. They assume that they must immediately take action not to aggravate the situation further. The research results in the flow of the Proximity indicator or the Proximity of the researchers explain how the study results relate to the perceived impact of problems related to Hajj and Umrah during the COVID-19 Pandemic Lampung Province. In the Proximity section, the researcher describes the impact directly felt geographically and worldly on people's lives.

The indicator of the flow of Proximity or the Proximity of the perceived impact, it can be concluded that in the case of hajj and Umrah during the COVID-19 Pandemic, all aspects are directly affected both in the economic, health, social, and religious fields. Moreover, the impact can be felt directly by prospective pilgrims for Hajj and Umrah in Indonesia and by prospective pilgrims worldwide. Another impact that is felt due to problems in Hajj and Umrah during the COVID-19 Pandemic is that tour and travel agents lose money due to the absence of departure activities to the Holy Land.

In principle, the Government under the coordination of the Minister is responsible for organizing Hajj and Umrah, a national task following Law Number 8 of 2019 concerning the Implementation of Hajj and Umrah. In its implementation, the pilgrimage and Umrah consist of various activities in other countries (Saudi Arabia), involving many people and involving many parties in providing services for activities carried out every year. Entering the COVID-19 Pandemic, which attacks almost all countries globally, impacts the health, economic, social, political, and religious. It also affects the implementation of Hajj and Umrah during the COVID-19 Pandemic.

The initial stage in a series of issues that can become government policy is agenda-setting or problem formulation. The agenda-setting stage is the Government's problem formulation stage, especially the Ministry of Religion, responsible for the Hajj and Umrah fields.

\section{CONCLUSION}

\subsection{Conclusion}

Issues of the problems in the formulation of the policysetting for the implementation of Hajj and Umrah are based on the theory of The 4P's. Agenda Setting proposed that: the Power possessed by the Regional Office of the Ministry of Religion in the policy setting schedule for the implementation of Hajj and Umrah during the COVID-19 Pandemic can be said to be weak. The Regional Office is only the executor, while the formulation of policy problems is in the Ministry of Religion of the Republic of Indonesia by considering Saudi Arabia's policies and the various perceptions of the relevant stakeholders. In addition, in formulating problems, the Government pays attention to the perceived proximity/impact due to the COVID-19 Pandemic, which has an impact not only in the religious field but also in social, economic, and health aspects. Suppose the Government does not address the problems related to the implementation of Hajj and Umrah during the COVID-19 Pandemic. In that case, it is feared that it will lead to worse potential/possibility in the future. The problem of hajj and Umrah during the Pandemic is a national and international concern, so it deserves to be a policy plan by the Government, especially the Ministry of Religion.

\subsection{Suggestion}

Hajj during the COVID-19 Pandemic is a challenge for the Government, especially the Directorate General of Hajj and Umrah Organization of the Ministry of Religion as the party responsible for organizing Indonesian Hajj and Umrah. The researchers provide suggestions for the Ministry of Religion of the Republic of Indonesia through the Directorate General of Hajj and Umrah Implementation. It is better to carry out more structured and systematic mitigation on a massive scale, especially to psychologically and socially prospective pilgrims. It can be done through social media or broadcast on television, such as talk shows to provide communication, information, and education about the implementation of Hajj and Umrah during the COVID-19 Pandemic. It also aims to prepare the hearts of prospective pilgrims and other parties affected by the cancellation of Hajj departures in 2020 and 2021.

\section{REFERENCES}

[1] Jokhdar, H., Khan, A., Asiri, S., Motair, W., Assiri, A., \& Alabdulaali, M. (2020). COVID-19 Mitigation plans During Hajj 2020: A Success Story of Zero Cases. Health Security, 19(2), 1-7. https://doi.org/10.1089/hs.2020.0144 
[2] Hamidah, Z. N. (2019). Kebijakan Pelayanan dalam Pengelolaan Identitas Jemaah Haji Tahun 2018 (Studi Pada Pembuatan Paspor Bagi Calon Jemaah Haji Reguler di Wilayah Yogyakarta). 2018.

[3] Taufiqurrokhman. (2014). Kebijakan Publik. In Fakultas Ilmu Sosial dan Ilmu Politik Universitas Maestopo Beragama (Pers) (Cetakan Pe, Issue 1993). Fakultas Ilmu Sosial dan Ilmu Politik Universitas Moestopo Beragama (Pers).

[4] Abdal. (2015). KEBIJAKAN PUBLIK (Memahami Konsep Kebijakan Publik). Pusat Penelitian dan Penerbitan Lembaga Penelitian dan Pengabdian Kepada Masyarakat UIN Bandung.

[5] Pratama, B. S. (2017). Analisis Keterlibatan Stakeholder dalam Program Revitalisasi Pasar Sukoharjo Kabupaten Pringsewu Tahun 2016. Skripsi Universitas Lampung.

[6] Puspita, R. I. (2016). ANALISIS PENYUSUNAN AGENDA KEBIJAKAN PUBLIK (STUDI KAJIAN AGENDA PENYUSUNAN KEBIJAKAN PENYELESAIAN PELANGGARAN RTRW OLEH INDUSTRI CV. EVERGREEN INDOGARMENT). Skripsi Universitas Diponegoro.

[7] Anggara, S. dan E. S. (2014). Kebijakan Publik Pengantar (cetakan ke). CV. Pustaka Setia.
[8] Rosidin, R. (2020). Inti Fiqih HAJI \& UMRAH. August 2013.

[9] Madani, M. (2011). AGENDA SETTING PENGELOLAAN SAMPAH PASAR DI KOTA MAKASSAR. Otoritas FISIP Universitas Muhammadiyah Makassar, 1(1), 11-24.

[10] Zahariadis, N. (2016). Handbook of public policy agenda setting. In Handbook of Public Policy Agenda Setting. Edward Elgar Publishing, Inc. https://doi.org/10.4337/9781784715922 